\title{
The optimization of coagulation-flocculation process in a conventional treatment water plant
}

\author{
PhD. eng. Daniela Gologan ${ }^{1}$, eng. Madalina Elena Popescu ${ }^{2}$ \\ ${ }^{l}$ Head of quality and treatment water department Paltinu Water Treatment Plant-Romania \\ ${ }^{2}$ PhD student Oil and Gas University of Ploiesti -Romania
}

\begin{abstract}
The assurance of the protection for the delivered drinking water against the secondary pathogenic increases in the distribution network will become a prime importance target for water treatment plants. In the waterworks there are used the multi barrier concept, and each treatment step will have to be optimized to obtain a maximum reduction of the compounds which are a health hazard to consumers. The optimization of the coagulation flocculation process in order to obtain an advanced reducing of suspensions, organic substances and microbiological constituents has a positive effect on the other technological phases such as decantation, filtration, disinfection, ensuring the risk reduction of bacterial growth in the distribution network.
\end{abstract}

Keywords : coagulation, flocculation, multibarrier concept,pathogenic hazard control.

\section{Introduction}

Drinking water must be free of microorganisms, parasites or substances, which, in numbers or concentrations, constitute a potential danger to human health [1]. This requirement has become a challenge for water supply systems due to the resistance of some pathogens (Giardia, Cryptosporidium) at disinfection processes.

That's why, the U.S.A, Canada, Norway had implemented the multiple barriers concept in surface water treatment plants, for increase the efficiency in reducing suspensions, organic substances, microbial load of raw water [2].

Pathogens agents including protozoa parasites, bacteria and viruses can be physically removed by coagulation, flocculation, sedimentation and filtration, and then inactivated by disinfection. Therefore, the level of delivered water protection can be increased by optimizing the processes of removing the suspensions, knowing that a low turbidity level causes a low concentration of microorganisms [3].

In a conventional water treatment process, the coagulation and flocculation is the key stage which determining the particles destabilization and their agglomeration, which can then be removed by sedimentation and filtration processes. Effective use of these processes as part of a multi-barrier strategy for microbial protection represents an operational approach for the water producers.

Coagulation phaseis able to reduce $30-50 \%$ of the concentration of biodegradable organic carbon (BDOC) and between 50-80\% of assimilable organic carbon (AOC) [4]. The appearance of the pre-hydrolyzed coagulants and then of the bi-component ones, has increased the efficiency in reducing of the mineral, organic and microbiological content of the surface water used for drinking, while achieving the minimum residual metal concentrations $[5,6,7]$.

To increase the efficiency of coagulation processes, are used flocculants, the most widespread being the polyacrylamide type. Organic flocculants based on polyacrylamide are considered to have carcinogenic effect, that's why the maximum permissible residual concentration is $0.1 \mu \mathrm{g} / \mathrm{l}$ [8]. The residual acrylamide can form with chlorine, carcinogenic compounds. Because of these effects new flocculants and coagulants with complex structure, containing siliconhave appeared on the market. Research recently published show the positive role of silicon in the treatment of Alzheimer's disease [9].

Because the turbidity parameter is easily analyzed, with a wide range of equipment on line, it has developed a multi-barrier strategy resulting from the analysis of drinking water systems in the U.S.A, and correlation between turbidity and concentration of pathogens agents [10]. Thus, there have been proposed the following qualitative targets [2]:

obtain a turbidity below 1 NTU for decanted water, if raw water turbidity is below $10 \mathrm{NTU}$;

obtain a turbidity below 2 NTU, if raw water turbidity is more than $10 \mathrm{NTU}$;

obtain a turbidity of maximum $0.3 \mathrm{NTU}$ at filtered water before the final disinfection.

These qualitative targets requires time for implementation, because requires introduction of new technologies and reagents for treating, and also the optimizing of the amount of reagents used. 
In the latest edition of the National Primary Drinking Water Regulation [11] Environmental Protection Agency U.S. introduced systems, which have the conventional treatment flows, as $95 \%$ of samples analyzed for turbidity to be below 0.3 NTU.

The European Community requirement for filtered water turbidity which entering for disinfection in the treatment plants, which using surface sources, is that it should be below 1 NTU [1].

\section{Experimental Part}

This paper presents qualitative and economic implications when optimizing coagulation-flocculation phase, so that the settled water turbidity to decrease by $\sim 50 \%$ using a conventional flux for treating, projected for the year 1970 level. The experimental research was conducted in Water Treatment Plant Paltinu, The average inlet flow of raw waterin the treatment plant is $550 \mathrm{l} / \mathrm{s}$.

The technology of water treatment plant includes the following steps: coagulation, flocculation, sedimentation, intermediate disinfection, filtration on quartz sand, final disinfection. Sedimentation process occurs in two decanters of $\sim 5000 \mathrm{~m}$, radial with scraper bridge type. The disinfection step(intermediate and final used chlorine.

Raw water which supplies treatment plant comes from an artificial lake - the Paltinu Dam - and for optimized the coagulation-flocculation phase are used a pre-hydrolyzed bi-component coagulant typepolyaluminum chloridehydroxide sulfateand a flocculant based on polysilicate - Cettaclear.

The low efficiency in terms of reduction of the turbidity (average turbidity of settled water $\sim 6.5 \mathrm{NTU}$ ), and the microbiological contents of the sedimentation phase (bacterial reduction efficiency $\sim 50 \%$, the filtration cycle approximately 30 hours) have determined the optimization the coagulation-flocculation phase by use the performed coagulant and flocculant and applying in the technological process their optimal dose.Optimal dose is the amount of reagent that offers the best combination ofturbidity reduction efficiency, organic components reduction efficiency, low concentration of residual aluminum, reduced effect on the raw water's $\mathrm{pH}$ level.

To obtaining a low turbidity at the exit from the settlers, ensure the yield increasing, of the suspensions reducing, organic and microbial content, but also increase the efficiency of filtration and disinfection phase.

Therefore, to optimize coagulation-flocculation phase was chosen as a qualitative target, a turbidity of the settled water should by below 3 NTU. This limit has been chosen because it was taken into account the radial settler performance.

In this regard, the following measures were established:

- the determination of the optimal dose (grams coagulant or flocculant for each raw water cubic meter) of coagulant and flocculent by Jar test method, so that the turbidity of the decanted water to be between 2.0 and 3.0 NTU:

- the using of the optimal dosage established in the technological flow and rapid adaptation of these at the quality changes of the of raw water;

- $\quad$ the residual concentration of aluminum in the potable water does not exceed $0.1 \mathrm{mg} / \mathrm{l}$;

- the increase of the frequency of analysis of the relevant parameters of the technological process: turbidity, $\mathrm{pH}$, organic substances, aluminum and residual chlorine;

- $\quad$ monitoring the consumption of the treating reagent, and of the technological water.

\section{Results And Discussions}

To assess the settled water turbidity reduction to below 3 NTU, were analyzed the results of chemical and microbiological analysis, the reagent consumption of the water treatment process, which were cumulated during 174 days, the first 87 days showing non-optimized situation.

The average values regarding the technological process efficiency in optimized and non-optimized version of the settler step are presented in Table 1.

Table 1

The parameters of settled phase during experiment, specific consumption of the reagents

\begin{tabular}{|l|l|l|l|l|l|}
\hline Process type & $\begin{array}{l}\text { Average raw } \\
\text { waterturbidity }\end{array}$ & $\begin{array}{l}\text { average } \\
\text { coagulant } \\
\text { dose }\end{array}$ & $\begin{array}{l}\text { average } \\
\text { flocculant } \\
\text { dose }\end{array}$ & $\begin{array}{l}\text { Average } \\
\text { settled } \\
\text { water } \\
\text { turbidity }\end{array}$ & $\begin{array}{l}\text { The average } \\
\text { efficiencyreduction of } \\
\text { the turbidity of the settler } \\
\text { step EFRm }(T)_{d}\end{array}$ \\
\cline { 2 - 6 } & $\mathrm{NTU}$ & $\mathrm{g} / \mathrm{mc}$ & $\mathrm{g} / \mathrm{mc}$ & $\mathrm{NTU}$ & $\%$ \\
\hline non-optimized & 16,87 & 12,5 & 0,069 & 6,2 & $63 \%$ \\
\hline optimized & 16,54 & 16,7 & 0,096 & 2,9 & $82 \%$ \\
\hline
\end{tabular}


Average efficiency reduction of the turbidity at settled phase was calculated regarding equation (1)

$$
\operatorname{EFRm}(T)_{d}=\frac{T_{m(\text { raw })}-T_{m(\text { decanted })}}{T_{m(\text { raw })}}
$$

Where:

EFRm $(\mathrm{T})_{d}$ - the average efficiency in reducing turbidity on decanted step

$\operatorname{Tm}($ raw $) \quad$ - average turbidity of raw water during the experiment -[NTU]

$\operatorname{Tm}($ decanted $)$ - average turbidity of settled water during the experiment -[NTU]

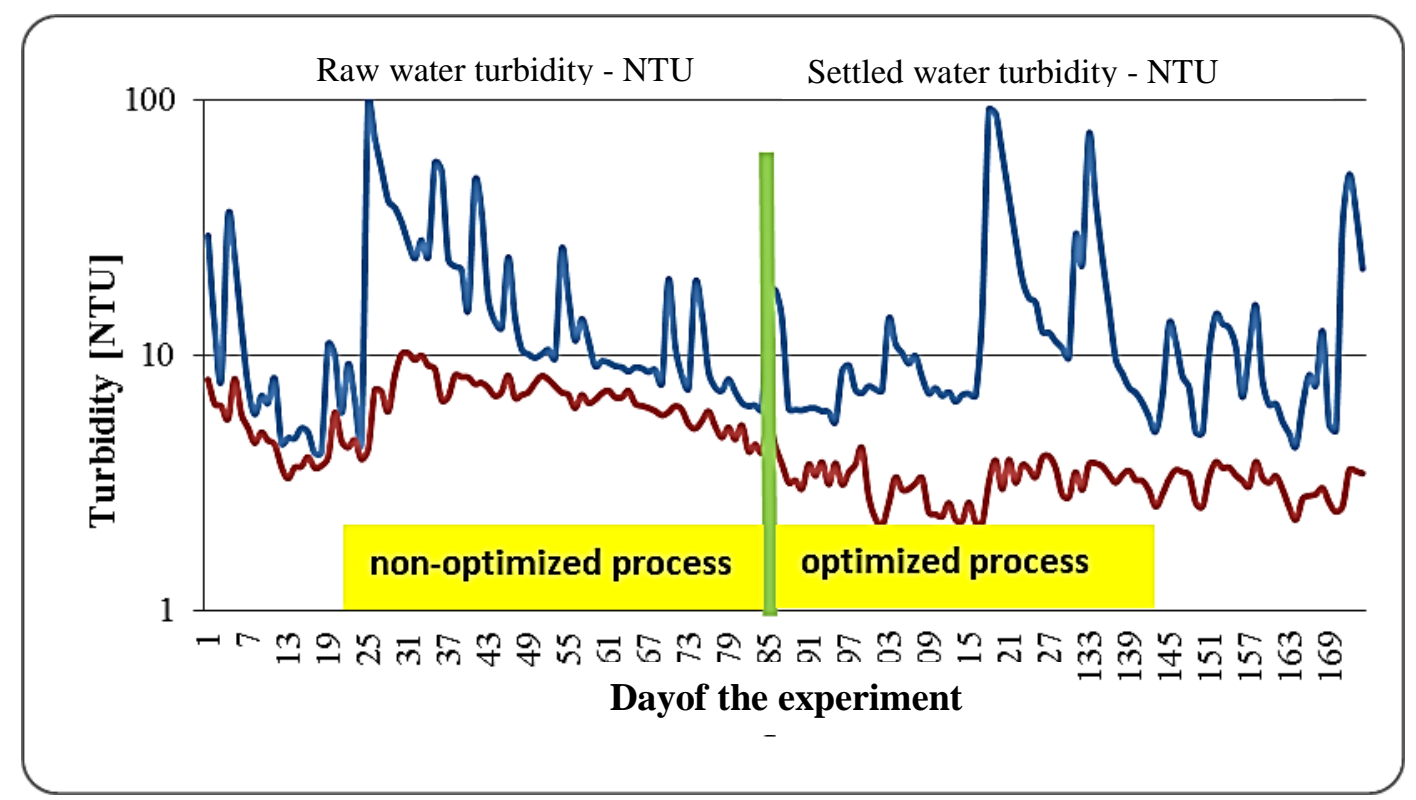

Fig. 1 - Raw and settled water turbidity during the experiment

The turbidity of raw water in both periods of the experiment was comparable, an average value of 16.87 NTU in non-optimized variant and 16.54 NTU in optimized variant - figure 1.

The optimization of the coagulation-flocculation process has resulted in increased efficiency of turbidity reduction both for decanted steps and for whole process technology - Table 2.

Table 2

Disinfection and filtration process parameters during the experiment

\begin{tabular}{|l|l|l|l|l|}
\hline Process type & $\begin{array}{l}\text { Average chlorinedose, } \\
\text { intermediate } \\
\text { disinfection }\end{array}$ & $\begin{array}{l}\text { Filtrated water } \\
\text { turbidity }\end{array}$ & $\begin{array}{l}\text { Average } \\
\text { chlorinedose, final } \\
\text { disinfection }\end{array}$ & $\begin{array}{l}\text { Overall average reductionefficiency of } \\
\text { turbidity for whole treatment process } \\
E F R m(T)_{g}\end{array}$ \\
\cline { 2 - 5 } & $\mathrm{g} / \mathrm{mc}$ & $\mathrm{NTU}$ & $\mathrm{g} / \mathrm{mc}$ & $\%$ \\
\hline non-optimized & 0.83 & 0.63 & 0.71 & 96 \\
\hline optimized & 0.67 & 0.37 & 0.55 & 98 \\
\hline
\end{tabular}

The average overall efficiency of the turbidity reduction was calculated according to equation (2).

$$
\operatorname{EFRm}(T) g=\frac{T_{m(\text { raw })}-T_{m(\text { filtrated })}}{T_{m(\text { raw })}}
$$

where:

$\operatorname{EFRm}(\mathrm{T})_{g}$ - the overall average efficiency in reducing turbidity

$\operatorname{Tm}($ raw $) \quad$ - average turbidity of raw water during the experiment -[NTU]

$\operatorname{Tm}($ decanted $)$ - average turbidity of decanted water during the experiment -[NTU]

Thus, the turbidity reduction efficiency on settled step increased from 63 to $82 \%$, and the overall efficiency one, which includes also the filtration step, from 96 to 98\%: (fig. 2).

The dose of disinfectant (specific consumption) in both of intermediate and final stages decreased with $17 \%$ and $20 \%$ : Figure 3. 


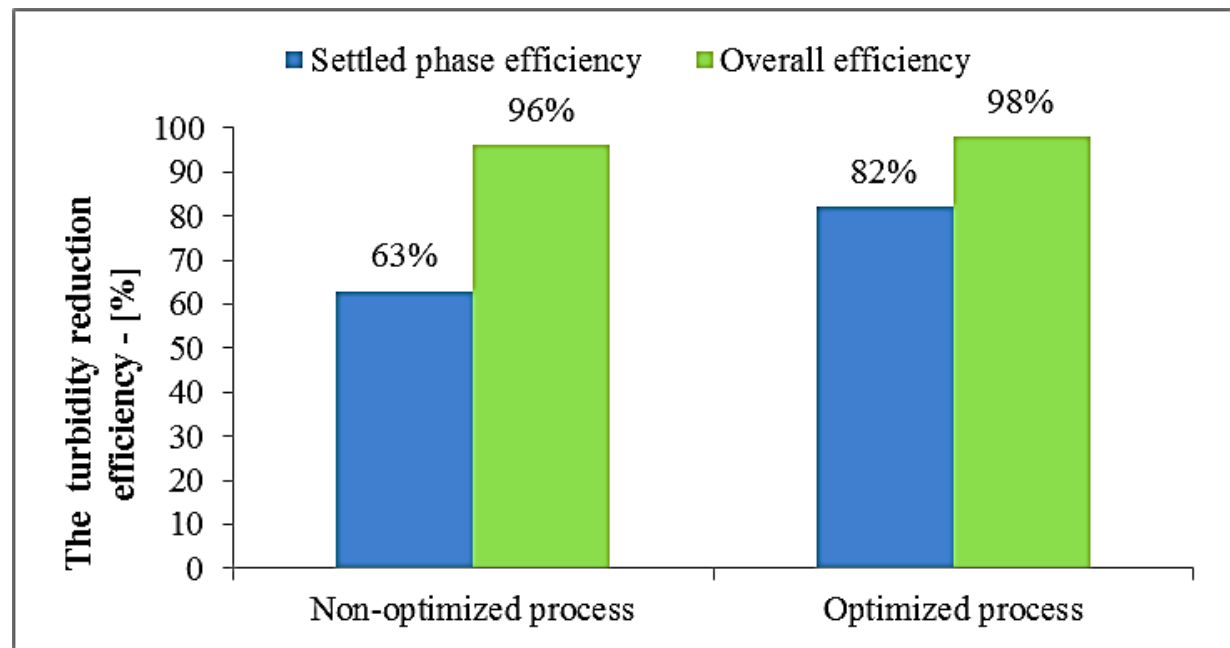

Fig. 2 - The overall efficiency of the technological process and settled phase efficiency in optimized and non-optimized process

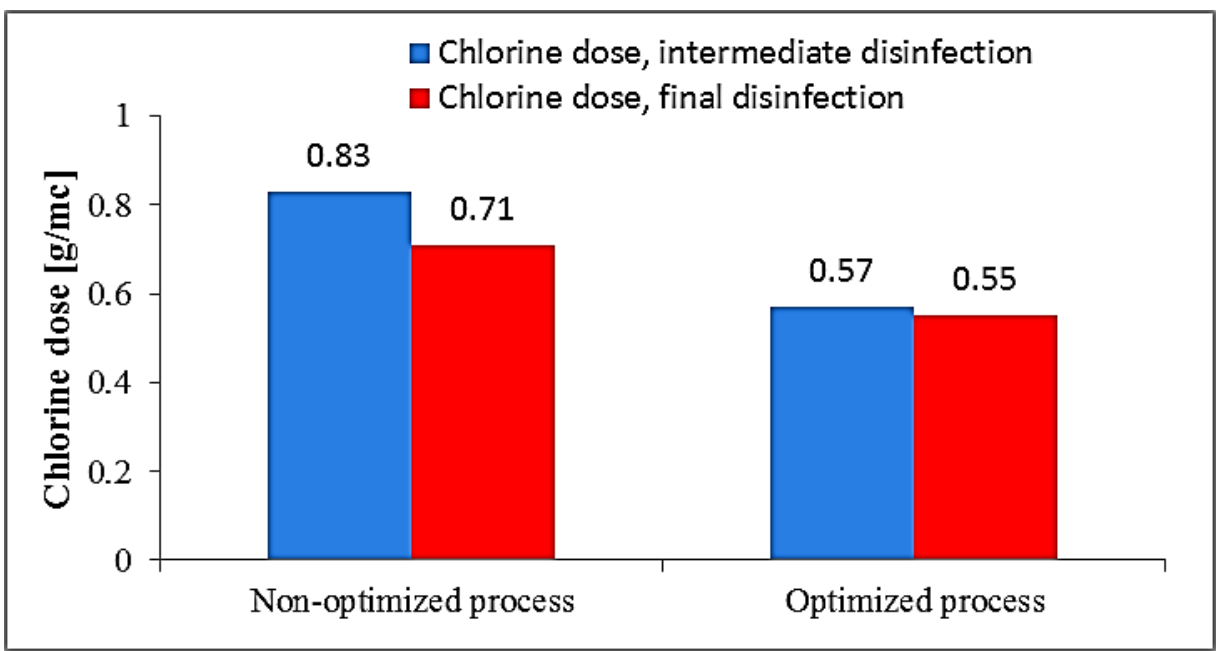

Fig. 3 Dose of disinfectant on intermediate and final phase disinfection

The turbidity of the filtered water was reduced from 0.63 NTU to 0.37 NTU- such that the impact of the coagulation flocculation optimization phase on filtration stage is significant, registering a reducing of $70 \%$ Figure 4.

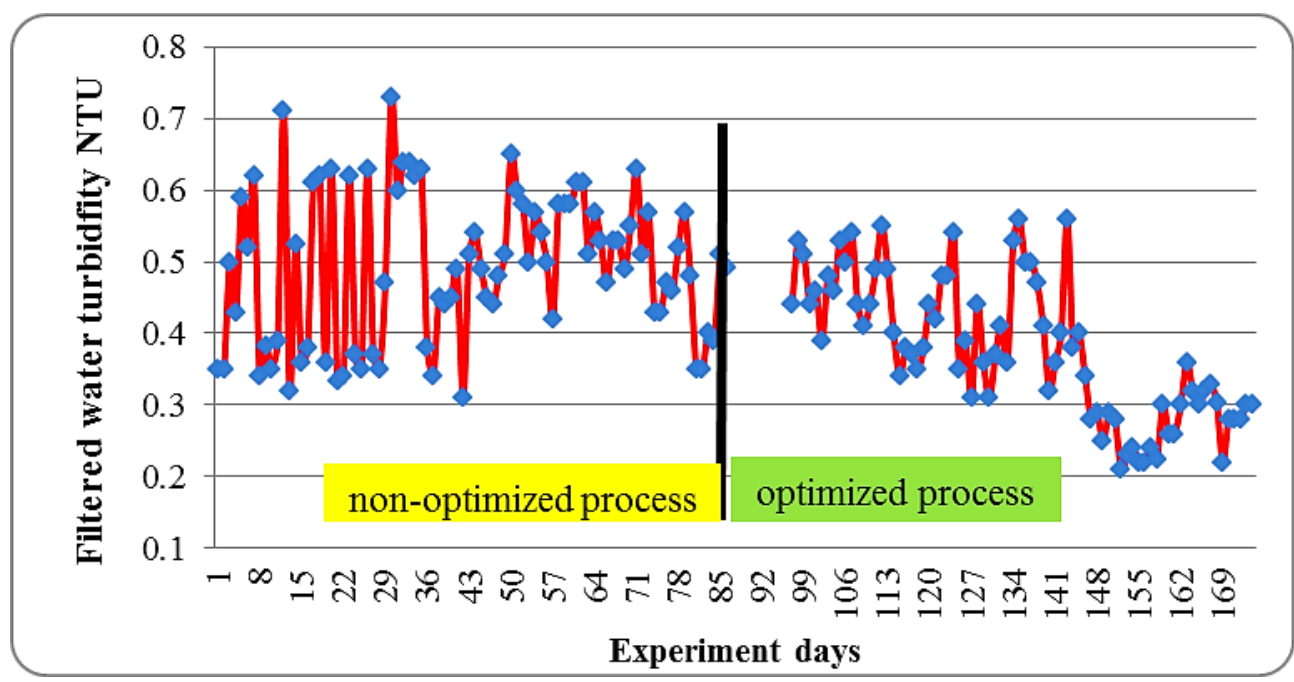

Fig. 4 - Filtered water turbidity during the experiment 
Filtration cycle are increased by approximately $30 \%$, from an average of 30.5 hours to 40.2 hours with positive effect on the consumption of technological water, which decreased by $-20 \%$, which reduced the raw water flow, given that the filters washing is done with drinking disinfected water. Technological consumption due to remove de sludge at radial settler increases, because increasing volume of sludge deposited.

Table 3

Filtration cycle and technological consumption

\begin{tabular}{|l|l|l|l|l|l|}
\hline $\begin{array}{l}\text { Process } \\
\text { type }\end{array}$ & $\begin{array}{l}\text { The } \\
\text { average } \\
\text { filtration } \\
\text { cycle }\end{array}$ & $\begin{array}{l}\text { Average } \\
\text { technological } \\
\text { consumptionto } \\
\text { remove settled } \\
\text { sludge }\end{array}$ & $\begin{array}{l}\text { Average } \\
\text { technological } \\
\text { consumption } \\
\text { washing filters }\end{array}$ & $\begin{array}{l}\text { Total } \\
\text { average } \\
\text { technological } \\
\text { consumption }\end{array}$ & $\begin{array}{l}\text { Average } \\
\text { technological } \\
\text { consumption at raw } \\
\text { water flow inlet }\end{array}$ \\
\cline { 2 - 6 } & hours & mc/month & mc/month & mc/month & $\%$ \\
\hline $\begin{array}{l}\text { non- } \\
\text { optimized }\end{array}$ & 30.5 & 16043 & 162219 & 178263 & 11.94 \\
\hline optimized & 40.2 & 19400 & 129775 & 149175 & 10.03 \\
\hline
\end{tabular}

The action on the reduction of the organic and pathogens loads is shown in Table 4.

Table 4

The reduction efficiency of organic and microbial content

\begin{tabular}{|l|l|l|l|l|l|}
\hline Process type & \multicolumn{3}{|l|}{$\begin{array}{l}\text { Reducing the concentration of organic substances } \\
\text { decantation on stage }\end{array}$} & $\begin{array}{l}\text { Reducing pathogenic bacteria } \\
\text { decantation on stage }\end{array}$ \\
\cline { 2 - 6 } & $\begin{array}{l}\text { index } \\
\text { permanganate } \\
\mathrm{mg} / 1 \mathrm{O}_{2}\end{array}$ & $\mathrm{UV}_{254}$ & $\begin{array}{l}\text { Coliform } \\
\text { bacteria } \\
\mathrm{nr} / 100 \mathrm{ml}\end{array}$ & $\mathrm{nr} / 100 \mathrm{ml}$ & $\begin{array}{l}\text { Enterococci } \\
\text { Pr/stringens }\end{array}$ \\
\hline non-optimized & $34 \%$ & $23 \%$ & $52.4 \%$ & $55.2 \%$ & $57.6 \%$ \\
\hline optimized & $56 \%$ & $28 \%$ & $77.6 \%$ & $76.4 \%$ & $79.7 \%$ \\
\hline
\end{tabular}

Turbidity reducing on the settled stage is directly proportional to the reduction degree of organic substances and pathogenic bacteria, which is reflected also in the specific consumption decrease of disinfectant.

The concentration of residual aluminum in the water supplied was 112 microgram/l in the nonoptimized versionand 84 microgram/l in optimized version, so the reduction was $\sim 25 \%$

The consumption of treatment reagent increased such: the coagulant has registered a growth of $34 \%$, and the flocculent an increase of $39 \%$ - Figure 5, 6

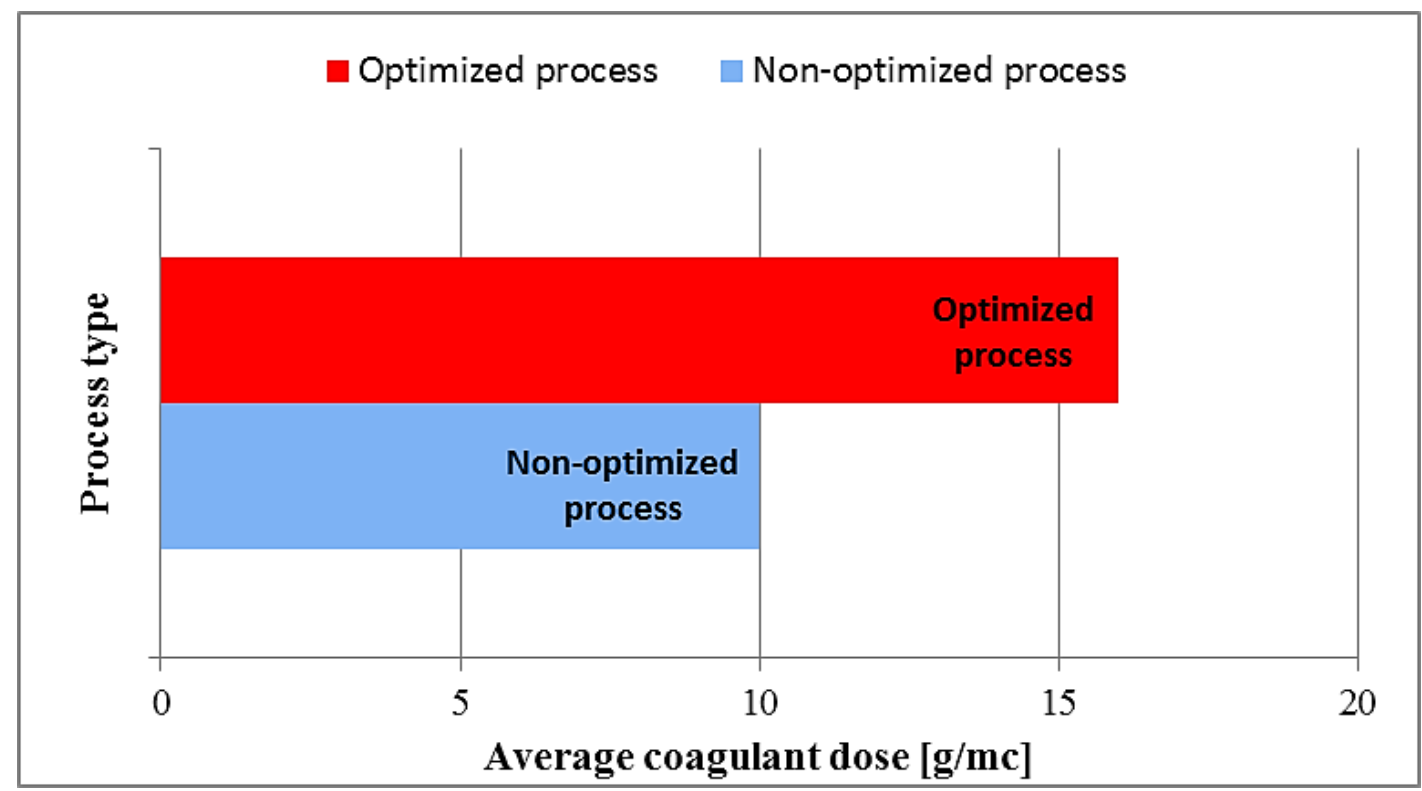

Fig. 5 Coagulant specific consumption during the experiment 


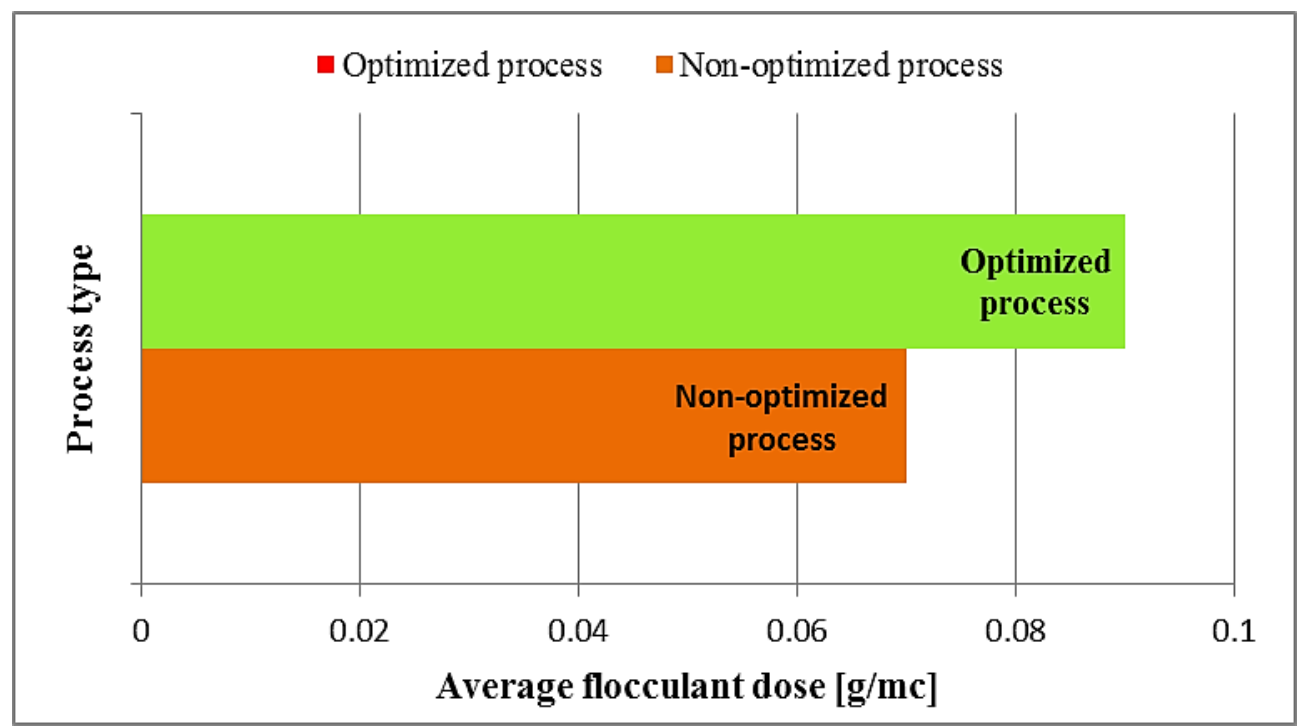

Fig. 6 Flocculant specific consumption during the experiment

The optimization of coagulation-flocculation process by advanced reducing of the suspensions of the raw water, and getting the turbidity of settled water by 3 NTU determine:

- $\quad$ increased the cost with coagulant and flocculant;

- decreased the cost with disinfectant;

- costs reducing with raw water by decreasing consumption water for washing filters;

- lowering energy costs, used at wash filters equipment (pumps, blowers).

The calculation for material costs, in optimized variant, show an increase with $6.5 \%$ compared to nonoptimized version

\section{Conclusion}

Increasing the efficiency of coagulation flocculation phase has following advantages:

- decreases the suspensions content from settled water;

- decreases the organic and pathogen content both in settled phase and in filtering phase;

- increase the filtration step efficiency;

- decreases energy consumption and water for washing filters;

- decreases disinfectant consumption both on intermediate stage and in final one;

The disadvantage is:

- increased consumption of coagulation flocculation reagents.

The additional costs of coagulant and flocculent are partly covered by the decrease of technological consumption and the amount of disinfectant, and so the increasing of material costs of the whole technological process is $\sim 6.5 \%$.

Ensure protection of delivered water against pathogenic increases in distribution network will become a primary importance for water producers.

To respect the quality requirements for potable water and to protect against secondary bacterial growths delivered into the distribution system, water providers will need to focus on bio-flocculants and coagulants with a complex structure, in order to reduce the impact on consumer health. When choosing a coagulation reactant over another, the balance between its technological efficiency and the material resources available should be taken into account.

The implementing of concept of multi-barrier in water treatment plants in which each treatment step will be optimized. To obtain maximum reduction of compounds that represent a health risk to consumers can be a useful tool to determine notable results in increased the performance of water treatment plants.

A risk treatment process analysis, determining critical control points by implementing safety plans in treatmentplant, provides a preventive approach and a framework for evaluating measures to reduce pathogens constituents. 


\section{References}

[1] 98/83/EC, Drinking Water Directive; The quality of water intended for human consumption; Official Journal of the European Communities 05.12.1998.

[2] USEPA,Optimizing Water Treatment Plant Performance Using the Composite Correction Program. EPA/625/6-91/027, Center for Environmental Research Information - Cincinnati, 1998.

[3] Consonery, P. J.,Evaluating and Optimizing Surface Water Treatment Plants: How Good is Good Enough? Paper presented at AWWA Water Quality Technology Conference, Boston, MA, 1996.

[4] E.P.A., ,Effect of Treatment on Nutrient Availability”, Office of Water (4601M), 2007.

[5] Gao, B., Yue,Q.Y.,Effect of $\mathrm{SO}_{4}{ }^{2-} / \mathrm{Al}^{3+}$ ratio and $\mathrm{OH}^{-} / \mathrm{Al}^{3+}$ value on the characterization of coagulant poly-aluminum-chloridesulfate (PACS) and its coagulation performance in water treatment, Chemosphere, 61(4):579-584, 2005.

[6] Gao, B., Yue, Q.Y., Poly-aluminum-silicate-chloride (PASiC) - a new type of composite inorganic polymer coagulant, Colloids Surf. A: Physicochem. Eng. Aspects 229 (1-3) 121-127, 2003.

[7] Gao, B.,Coagulation performance of polyaluminum silicate chloride(PASiC) for water and wastewater treatment, Elsevier, 2007.

[8] O.M.S.,Guidelines for Drinking-water Quality, 2011;

[9] Exley, C.,A Silicon - Rich Mineral Water Therapy for Alzheimer's Disease,Journal of Alzheimer's Disease Vol. 33, No. 2, 2012.

[10] Nieminski, E. C.,-Removing Giardia and Cryptosporidium by Conventional Treatment and Direct Filtration,.Journal AWWA, 87 (9): 96, 1995

[11] EPA,National Primary Drinking Water Regulations - U.S.A, 2009 